\title{
Baseline Assessment of Seagrass Communities of Lubang and Looc Islands, Occidental Mindoro, Philippines
}

\section{$\operatorname{AUTHOR}(\mathrm{S}):$}

GENITO, GENIBETH E.; NABUAB, FENELYN M.; ACABADO, CRISTY S.; ALBASIN, BELLA SHEILA; BELDIA II, PACIFICO D.

\section{CITATION:}

GENITO, GENIBETH E.... [et al]. Baseline Assessment of Seagrass Communities of Lubang and Looc Islands, Occidental Mindoro, Philippines. Publications of the Seto Marine Biological Laboratory. Special Publication Series 2010, 10: 53-64

\section{ISSUE DATE:}

2010

URL:

http://hdl.handle.net/2433/144638

RIGHT: 


\title{
Baseline Assessment of Seagrass Communities of Lubang and Looc Islands, Occidental Mindoro, Philippines
}

\author{
Genibeth E. Genito ${ }^{1}$, Fenelyn M. Nabuab ${ }^{1}$, Cristy S. Acabado ${ }^{1}$, \\ Bella SheIla Albasin ${ }^{2}$ and Pacifico D. Beldia II ${ }^{1,3}$ \\ ${ }^{1}$ Marinebio and OceanBio Laboratories, College of Arts \& Sciences, \\ University of the Philippines Visayas, Miag-ao, Iloilo \\ ${ }^{2}$ The Marine Science Institute, University of the Philippines, Diliman, Quezon City \\ ${ }^{3}$ Conservation International-Philippines \\ E-mail: gengenito@gmail.com \\ Telefax: +63333159271
}

\begin{abstract}
The Lubang and Looc Islands in Occidental Mindoro are located west and form part of the Verde Island Passage (VIP), an ecologically important corridor linking the South China Sea and the Philippine internal waters. The VIP has also been labelled as a regional hotspot for tropical marine biodiversity, highlighting the need for management and conservation efforts that are science-based. Thus, this assessment was done to provide baseline data on the seagrass beds of the Lubang and Looc Islands.
\end{abstract}

Thirteen sites were surveyed around the Lubang and Looc Islands, Occidental Mindoro on April $13-17,2009$. The seagrass beds are generally multispecific meadows that are characterized by both continuous and patchy meadows, with cover ranging from $0.62 \%$ to $59.49 \%$. Eight seagrass species were observed, with Thalassia hemprichii and Cymodocea rotundata the most ubiquitous. Shoot densities observed in the area are generally high $\left(\right.$ mean $=961$ shoots $\cdot \mathrm{m}^{-2}$ ), and composite leaf biomass $\left(\right.$ mean $=212.70 \mathrm{gDW} \cdot \mathrm{m}^{-2}$ ) is comparable to other seagrass beds surveyed in other sites in the country.

The observed "kaingin" practices in the uplands pose the greatest threat to the seagrass ecosystems of the area because of the long-term domino effect of erosion and sedimentation on the seagrass beds. However, fisheries practices also need to be quantified to determine hierarchy of anthropogenic disturbance that causes habitat fragmentation of the seagrass beds of Lubang and Looc Islands.

Key words: Lubang and Looc Islands, multispecific, shoot density, leaf biomass

\section{Introduction}

Seagrasses are a prominent component of Philippine coastal ecosystems (Fortes, 1995). They are biota and habitat in one, as they naturally and simultaneously function both as primary producers and structural species. Consequently, they form ecosystems of great physical, biological, and economic importance (Baron et al., 1993), as they sustain a diversity of fauna, act as nutrient sinks and sedimentation buffers, and generally support important human exploitation (Hirst and Attrill, 2008; van Houte-Howes et al., 2004; Paula et al., 2001). Moreover, precisely because they are ecological constants of shallow coastal areas, they are rendered vulnerable to habitat fragmentation and sediment loading mostly brought about by anthropogenic activities (Hirst and Atrill, 2008; Tanner, 2005; Fortes \& Santos, 2004).

The ecological importance of seagrass habitats has long been recognized (Frost et al., 1999). However, their conservation and management in the country are not at par because of gaps in 


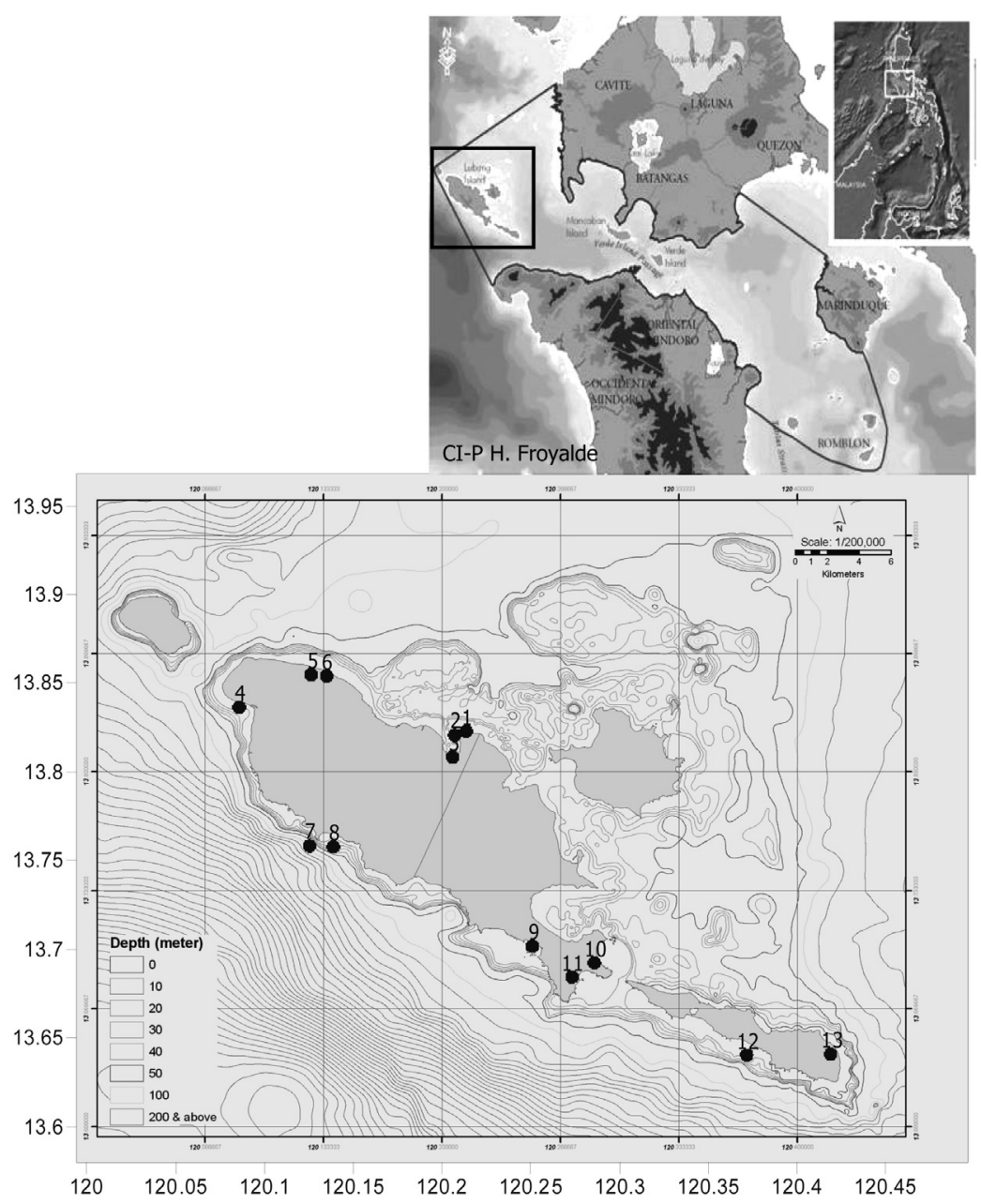

Fig. 1. Map of seagrass sites surveyed in Lubang and Looc Is., Occidental Mindoro, April 2009.

systematic and comprehensive data gathering and clear policy objectives on seagrass communities (BINU, 2005), as well as a lack of appreciation of the resources (Fortes \& Santos, 2004).

The objective of this study was to provide baseline assessment of the seagrass beds in Lubang and Looc Islands, Occidental Mindoro, Philippines. These islands are located west and form part of the Verde Island Passage (VIP), which is an ecologically important corridor linking the South China Sea and the Philippine internal waters. The VIP has also been labelled as a regional hotspot for tropical marine biodiversity, thus highlighting the need for management and conservation efforts that are science-based.

\section{Materials and Methods}

\section{Study area and sampling}

The study was conducted in 13 sites in Lubang and Looc Islands, Occidental Mindoro, Philippines on April 13 - 17, 2009 (Fig. 1). At each seagrass site, transect/s were laid perpendicular to 


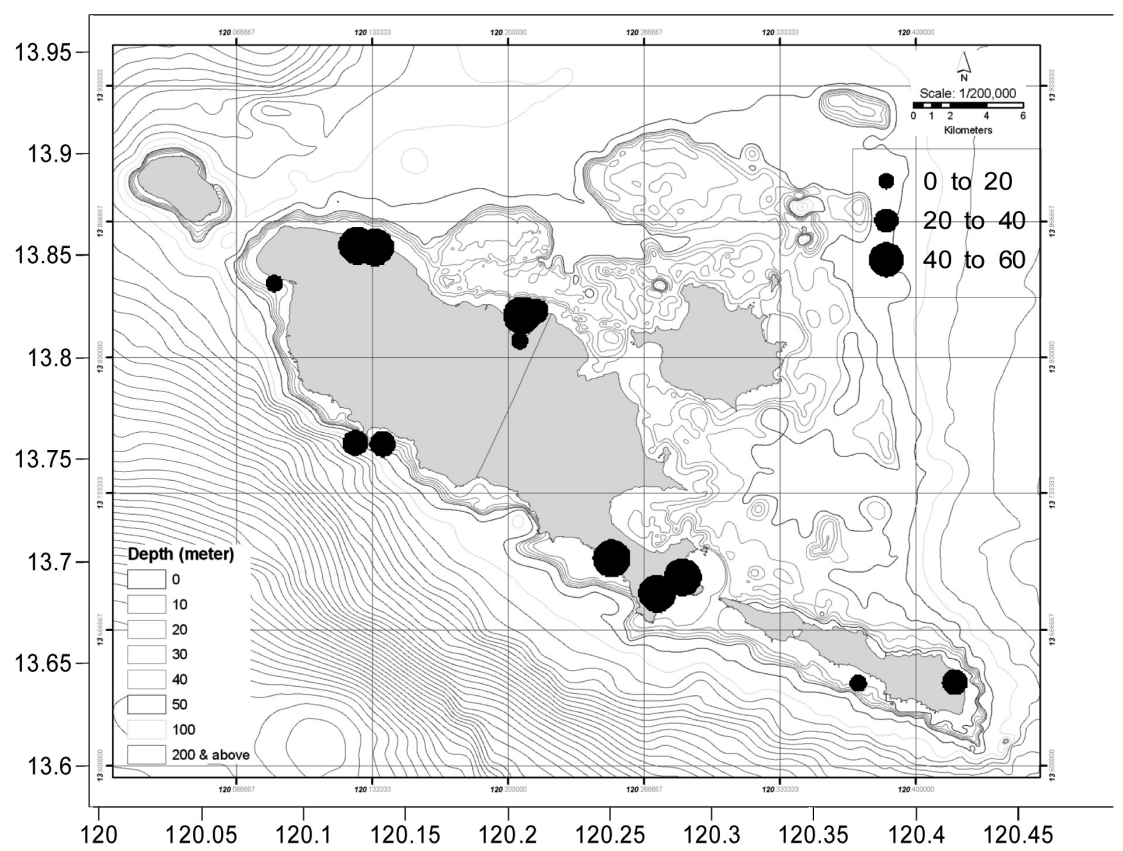

Fig. 2. Distribution of \% cover of seagrass in surveyed areas in Lubang and Looc Is., Occidental Mindoro, April 2009.

the shoreline. The length of each transect was dependent on the expanse of the grassbeds, with a maximum transect length of $100 \mathrm{~m}$ for extensive meadows.

\section{Seagrass cover, shoot density and leaf biomass}

Increments of $10 \mathrm{~m}$ along each transect were used as points for measuring percent cover, assemblage, shoot density, and leaf biomass. Percent cover was measured using the standard Saito Atobe method (English et al., 1994). At each point, the number of seagrass shoots per species was counted from a $50 \mathrm{~cm}^{2}$-quadrat to determine shoot density. Three random grids from the quadrat were chosen for harvesting seagrass to be used in biomass measurements.

To examine in the surveyed areas the continuum and persistence of seagrass growth against algal associations and non-vegetated patches, the LIT method (English et al., 1994) was applied. The method was also applied to examine possible zonation patterns in seagrass species distribution along a depth gradient.

\section{Results}

The surveyed seagrass communities were characterized by both continuous and patchy meadows, with cover ranging from $0.62 \%$ to $59.49 \%$ (sd: $16.75 \%$ ). The continuous and extensive meadows occurred mostly in the north side of the islands, while south of the islands were more patchy seagrass beds but with higher species heterogeneity. Survey results showed that 6 of the 13 sites have a generally moderate (40\%-60\%) cover, located along the northern coast (Transects $2,5 \& 6)$ and in the southeastern portion (Transects 9, $10 \& 11$ ) (Fig. 2). Moreover, results from the LIT showed that 10 out of 13 transects have a ground cover of more than $85 \%$, with a low percentage of algae and/or 


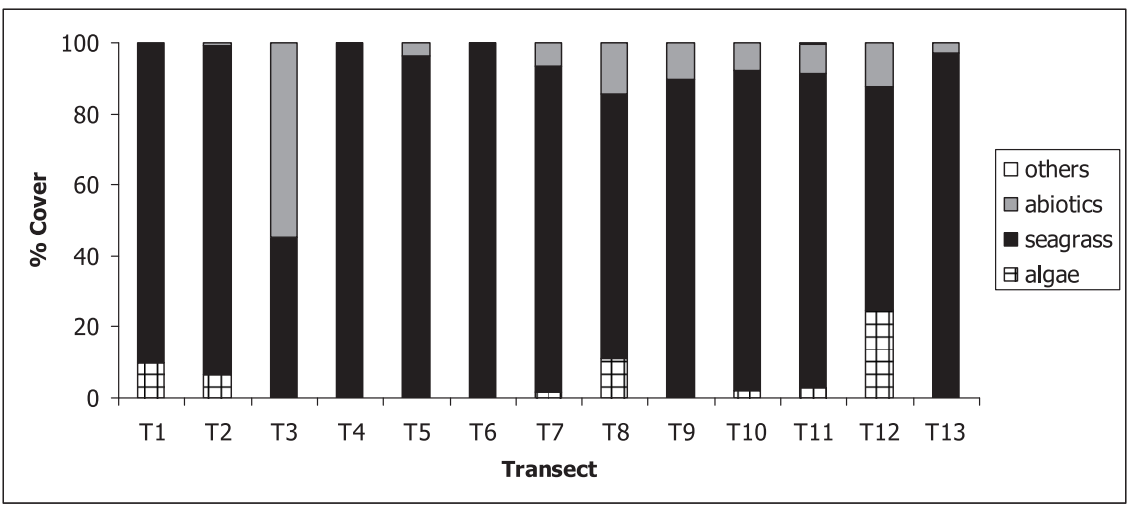

Fig. 3. LIT-based $\%$ cover of habitat structural components of seagrass beds in surveyed areas in Lubang and Looc Is., Occidental Mindoro, April 2009.

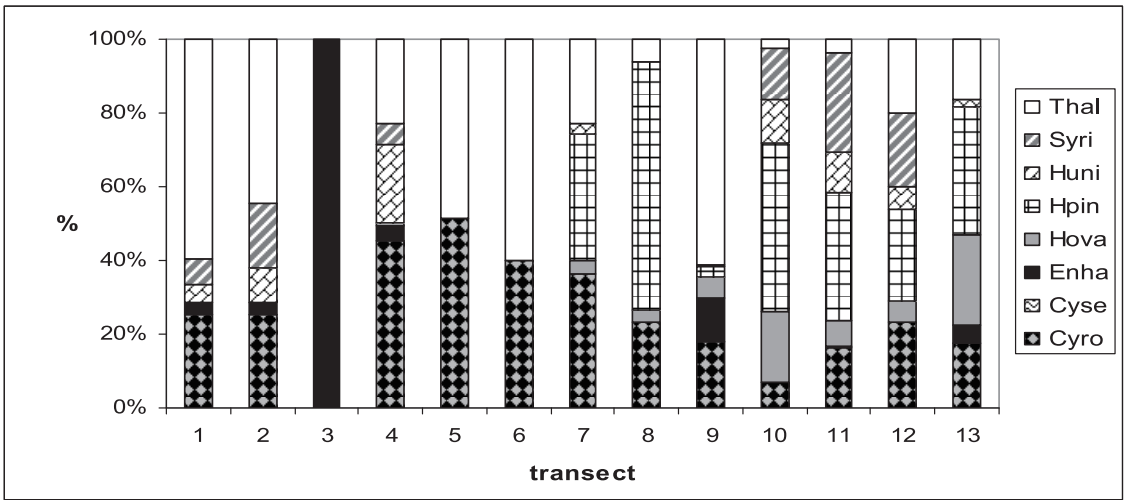

Fig. 4. Relative densities (\%) of the 8 seagrass species observed in the surveyed areas in Lubang and Looc Is, Occidental Mindoro, April 2009.

abiotic components (Fig. 3). Lowest seagrass ground cover was observed in Transect 3, where patches of bare sand are dominant $(54.58 \%)$.

Eight species of seagrass were found in the area, namely Cymodocea rotundata, Cymodocea serrulata, Enhalus acoroides, Halodule pinifolia, Halodule uninervis, Halophila ovalis, Syringodium isoetifolium, and Thalassia hemprichii (Table 1, Fig. 4). The occurrence of species ranged from a monospecific E. acoroides bed to a maximum of 7 species in mixed communities. Populations of $T$. hemprichii and $C$. rotundata provide consistent coverage with generally more species co-occurring in the eastern side.

Shoot density ranged from 16 to 2,010 shoots $\cdot \mathrm{m}^{-2}\left(\right.$ mean $=961$ shoots $\left.\cdot \mathrm{m}^{-2}\right)$, with the highest value in Transect 10 (Fig. 5), contributed mostly by $H$. pinifolia (45.83\%). Lowest density was observed in Transect 3, where the matrix of monospecific E. acoroides growth and bare sand patches span a vertical length of $48 \mathrm{~m}$, bordering the reef edge that has occasional submassive and massive coral heads (e.g. Porites). 


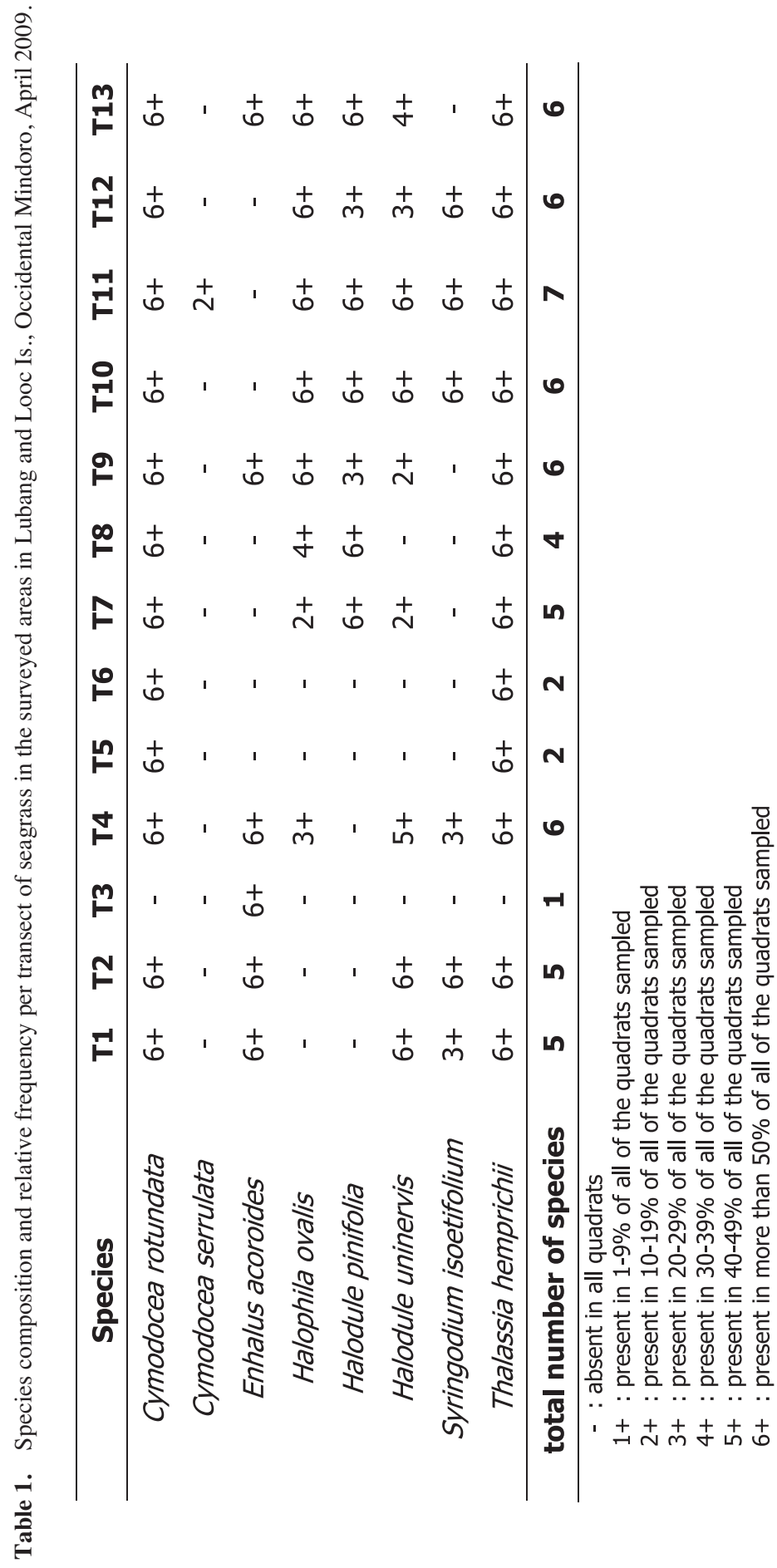




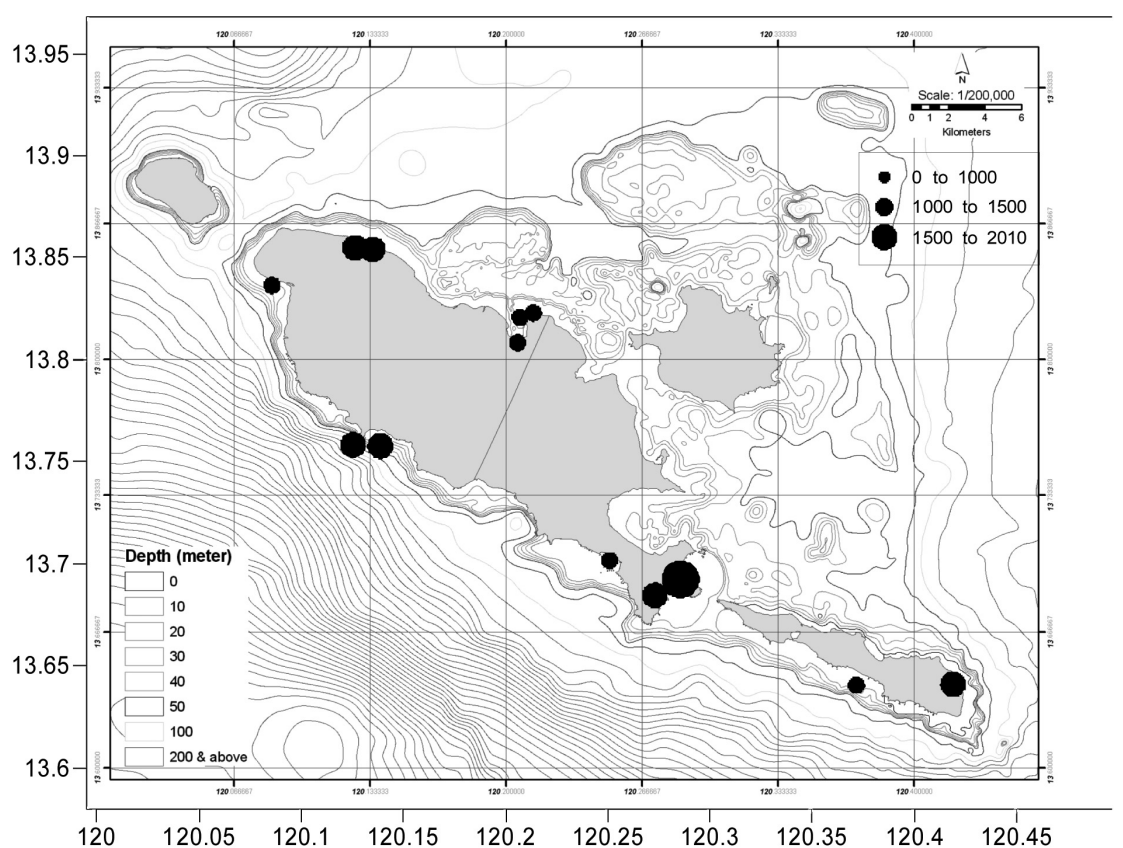

Fig. 5. Distribution of shoot density $\left(\right.$ shoots $\cdot \mathrm{m}^{-2}$ ) of seagrass in surveyed areas in Lubang and Looc Is., Occidental Mindoro, April 2009.

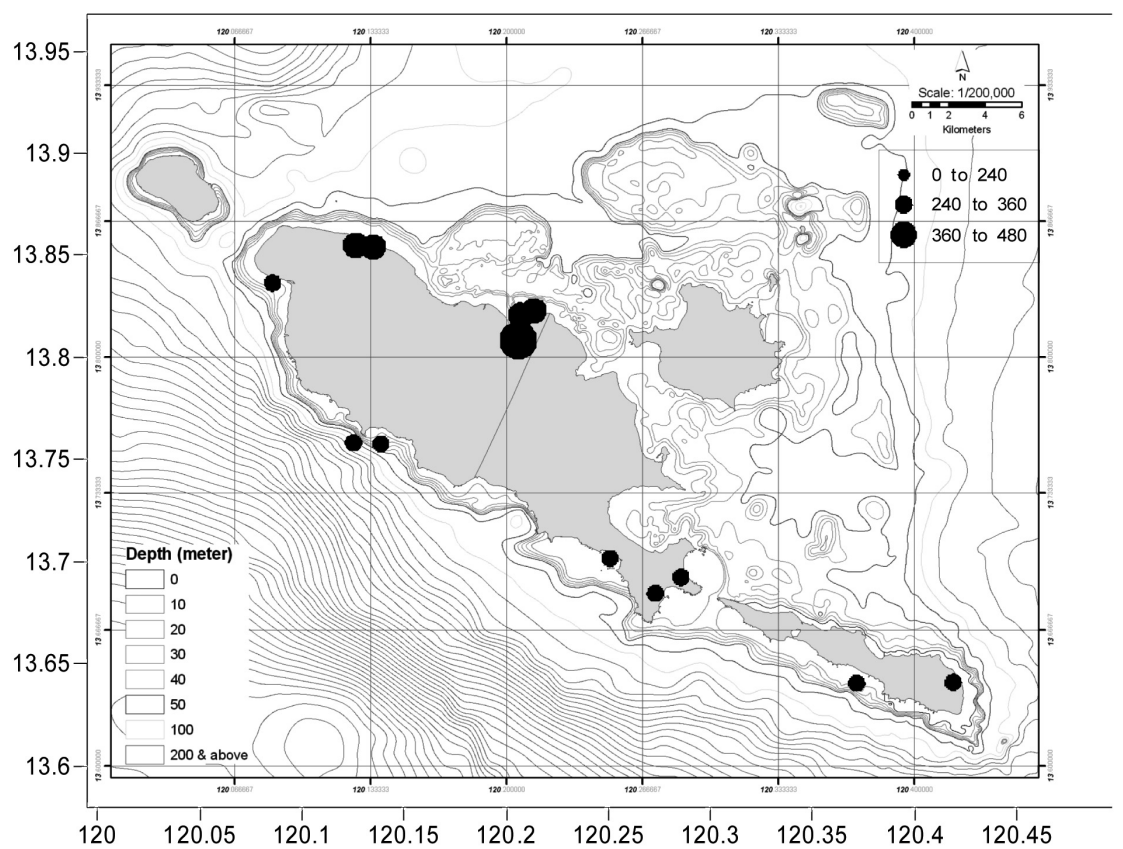

Fig. 6. Distribution of leaf biomass $\left(\mathrm{gDW} \cdot \mathrm{m}^{-2}\right)$ of seagrass in surveyed areas in Lubang and Looc Is., Occidental Mindoro, April 2009. 


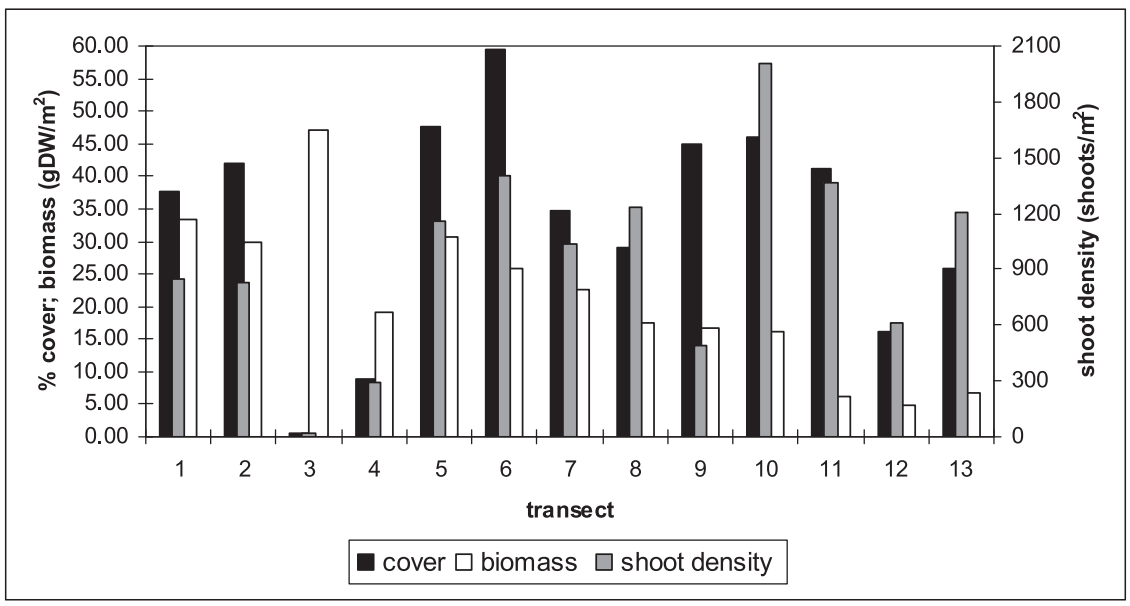

Fig. 7. Comparison of measured parameters of seagrass in surveyed areas in Lubang and Looc Is., Occidental Mindoro, April 2009. Note: Actual values of biomass were divided by 10 .

While seagrass cover and shoot density were generally high in the northwest and eastern portions, leaf biomass was high only in the northern part (Figs. $6 \& 7$ ). These areas are predominantly Thalassia-Cymodocea association (Fig. 3). Meanwhile, mean leaf biomass across all transects was $212.70 \mathrm{gDW} \cdot \mathrm{m}^{-2}\left(\mathrm{sd}: 121.56 \mathrm{gDW} \cdot \mathrm{m}^{-2}\right)$, with a range of $49.67 \mathrm{gDW} \cdot \mathrm{m}^{-2}$ (Transect 12$)$ to $471.25 \mathrm{gDW}$ $\cdot \mathrm{m}^{-2}$ (Transect 3$)$.

As aforementioned, the LIT method was applied in the survey to examine possible zonation patterns in seagrass species distribution along a depth gradient as represented by the transect line. Overall seagrass density was generally high nearshore. Detailed observation on each species shows that $C$. rotundata occurs densely nearshore, while $H$. ovalis and $H$. pinifolia occur in midwaters and $H$. uninervis and S. isoetifolium in deeper portions. Moreover, T. hemprichii and E. acoroides are indiscriminate species in relation to depth.

\section{Discussion}

The estimated percent cover of the seagrass beds in Lubang and Looc Islands, Occidental Mindoro, varies from low to moderate cover with $46 \%$ of the surveyed transects showing moderate cover, but mostly on the low-end values of the range. If to be treated on a larger scale, the overall mean estimate for the entire area is $33.37 \%$, which implies sparse (20-40\%) coverage, similar to Guimaras, which had a mean cover of $25.93 \%$ (range: $11.50 \%-48.10 \%$ ) in 1995 (Babaran \& Ingles, 1996) and $25.31 \%$ (range: $0.40 \%-73.60 \%$ ) in 2006 , immediately after an oil spill incident that hit the province (Nievales, submitted) (Table 2). In the Philippines, data for 26 different sites reported seagrass cover to be generally low, usually not exceeding $20 \%$, indicating that most of the seagrass beds in these areas have patchy cover (BINU, 2005).

The habitat structure of the surveyed seagrass beds is generally of multispecies composition, comparable to other seagrass beds surveyed in Palawan, Bolinao, Guimaras, and Negros Oriental, and even more diverse than southwestern Thailand and South Sulawesi, Indonesia (Table 2). Of the 8 


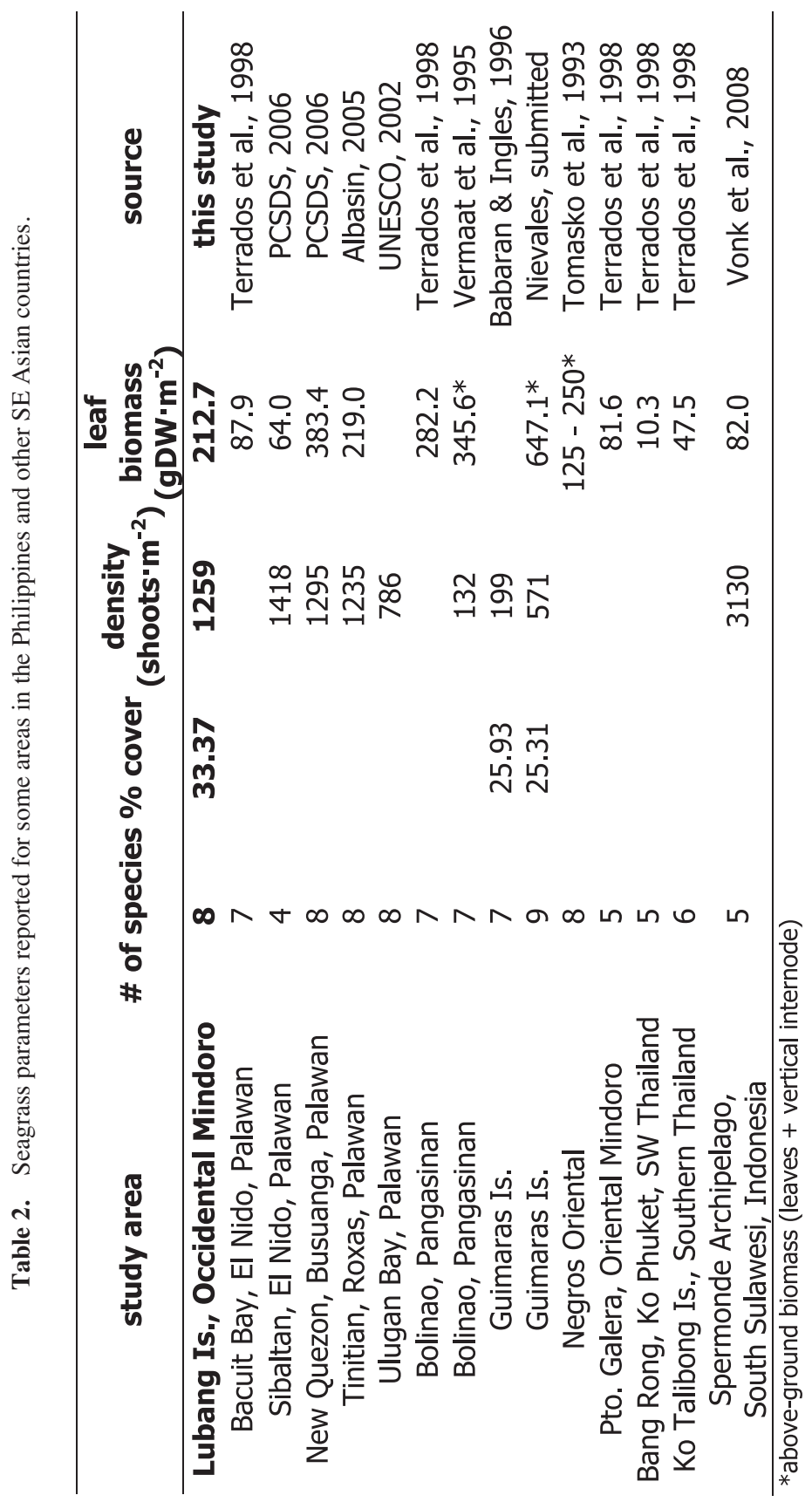


species found in the surveyed areas, T. hemprichii and C. rotundata both occurred in 12 of the 13 transects (Table 1, Fig. 3). In Bolinao, both species were also found to be the most proliferate (Vermaat et al., 1995), and in Guimaras (Nievales, submitted, Babaran \& Ingles, 1996) and Pto. Galera (Terrados et al., 1998), T. hemprichii was also the most ubiquitous seagrass species.

The ubiquitous co-occurrence of these two seagrass species compliments each other in such a way that $T$. hemprichii is a climax species, while $C$. rotundata is pioneering. The former occupy space more permanently, and accumulate and retain resources for extended periods of time, while the latter is best equipped to colonize new areas through rhizome expansion, or to wander from gap to gap within established beds (Vermaat et al., 1995). Thus, this balance ensures the maintenance of seagrass ground cover of the area.

Meanwhile, patchy monospecific E. acoroides bed was observed in Transect 3. It is highly likely that this homogeneity is a result of, or at least promoted by a relatively high sedimentation in the area, brought about by allochthonous inputs from the adjacent mangrove community as well as from the two small creeks opening up directly to the seagrass bed. The large, slow-growing E. acoroides is a climax species (Duarte, 1991) that has been demonstrated to be resilient to light reduction and enhanced sedimentation (Vermaat et al., 1995). In addition, the area is a locally important fishing ground, particularly drive-in gill net fishing for siganids. Moreover, it is located east of a high use embayment that serves as a docking port, and coastal settlement.

The overall mean shoot density of seagrass in the surveyed areas is comparable to those reported in other areas in the country, but lower by $40 \%$ as compared to South Sulawesi, Indonesia (Vonk et al., 2008) (Table 2). Seagrasses are usually considered to be dense if they exceed 400 shoots $\cdot \mathrm{m}^{-2}$ (Fortes, 1990). Thus, Lubang and Looc Islands appear to have a generally good seagrass density, with only two transects (Transects $3 \& 4$ ) falling from this criterion. The patchy monospecific E. acoroides bed in Transect 3 and the mixed meadow in Transect 4 have densities of 39 shoots $\cdot \mathrm{m}^{-2}$ and 296 shoots $\cdot \mathrm{m}^{-2}$ respectively. Both areas are high-use beachfronts, i.e. swimming area and docking port. C. rotundata accounts for $45.47 \%$ of the composite density of seagrass in Transect 4 .

Shoot density of the different species present across all sites surveyed ranged from $0.15(C$. serrulata) to 365.30 shoots $\cdot \mathrm{m}^{-2}$ (H. pinifolia). Density of the latter is due to its dominance in Transects $8 \& 10$ where they contribute $67.39 \%$ and $45.83 \%$ respectively to the composite shoot densities of the areas. H. pinifolia also has the highest density $\left(534.40\right.$ shoots $\left.\cdot \mathrm{m}^{-2}\right)$ in surveyed areas in Guimaras Is. (Babaran \& Ingles, 1996). Moreover, Transect 10 also harbors the highest densities of $H$. ovalis, as well as $H$. uninervis and $S$. isoetifolium. The higher density of $H$. ovalis (636.67 shoots • $\left.\mathrm{m}^{-2}\right)$ in the area, which is relatively deeper $(>2 \mathrm{~m})$ than the other sites, is a reflection of its low light requirement adaptive mechanism (Vermaat et al., 1995). Moreover, the area could be a possible dugong feeding ground, as what seem to be feeding tracks were observed, complemented by anecdotal accounts of fishermen of dugong sightings in their waters.

The total dry leaf biomass of the surveyed areas is relatively lower but comparable to that of Bolinao, Pangasinan (Terrados et al., 1998, Vermaat et al., 1995), Negros Oriental (Tomasko et al., 1993), and Roxas and Busuanga, Palawan (Albasin, 2005; PCSDS, 2006). At the same time, it is higher than reported values for Bacuit Bay, Palawan and Pto. Galera, Oriental Mindoro, as well as those observed in other Southeast Asian countries (Table 2). Highest leaf biomass $\left(471.25 \mathrm{gDW} \cdot \mathrm{m}^{-2}\right)$ was observed in the monospecific E. acoroides bed in Transect 3, while the lowest value (49.67 gDW $\mathrm{m}^{-2}$ ) was recorded in Transect 12. This area is a fragmented habitat, with a heterogeneous array of sand and coral rubble patches interspersed with algae (Padina sp.) and 6 species of seagrass that contribute $62.80 \%$ to the entire habitat structure of the area (Fig. 3). Furthermore, the dominants are 
the pioneering species (H. pinifolia, C. rotundata) that are smaller (UNESCO, 2002, Vermaat et al., 1995; Duarte, 1991) (i.e. unit area measures of biomass is a function of plant size (Fortes, 1990)). On the other hand, while Transect 3 has the lowest cover and density values, its high biomass could be a reflection of its aforementioned species composition.

The zonation of seagrass species with respect to depth is most likely driven by their competitive requirements for light and nutrients. The ubiquitous presence of climax species such as E. acoroides and $T$. hemprichii along the depth gradient is probably an indication, not only of the stability of the seagrass beds, but of their morphological advantage to thrive without significant interference from the other seagrass species. Meanwhile, C. rotundata, which is similarly sized, is best adapted nearshore, as compensation for its relatively lower elongation rates (Vermaat et al., 1995) which is otherwise a disadvantage in deeper waters, vertical elongation being an important factor in the competition for light. On the other hand, the other pioneering species are able to inhabit relatively deeper waters by having low light requirements, and faster and continuous rhizome growth (Vermaat et al., 1995).

\section{Summary, Conclusions and Recommendations}

The seagrass beds in Lubang and Looc Is., Occidental Mindoro, are generally multispecific meadows that are sparse to moderate in cover. Shoot densities of the 8 species observed in the area are generally high, and composite leaf biomass is comparable to other seagrass beds surveyed in other sites in the country.

In general, the observed "kaingin" practices in the uplands pose the greatest threat to the seagrass ecosystems of the area because of the long-term domino effect of erosion and sedimentation on the seagrass beds. However, fisheries practices also need to be quantified to determine hierarchy of anthropogenic disturbance that causes habitat fragmentation of the seagrass beds of Lubang and Looc Islands.

\section{Acknowledgments}

This study was funded by the Sulu-Sulawesi Seascape Program of the Conservation International-Philippines. Special thanks to Dr. Wilfredo L. Campos and Dr. Annabelle G. C. del Norte-Campos for their invaluable help and support.

\section{Literature Cited}

Albasin, B.S. 2005. unpublished report. Seagrasses and Seaweeds of Green Island Bay, Roxas, Palawan. Dugong Research \& Conservation Project, WWF-Philippines 32 pp.

Babaran, R.P. and J. Ingles. 1996. The coastal marine habitats of Guimaras Province: a rapid appraisal. Institute of Marine Fisheries and Oceanology. Miagao, Iloilo. 161-191 pp.

Baron, J., Clavier, J. and B.A. Thomassin. 1993. Structure and temporal fluctuations of two intertidal seagrass-bed communities in New Caledonia (SW Pacific Ocean). Marine Botany, 117, 139-144.

Biodiversity Indicators for National Use. 2005. BINU: Philippine Report on Coastal and Marine Ecosystems, UNEP-GEF-WCMC. BFAR-PAWB (Bureau of Fisheries and Aquatic Resources-Protected Areas and Wildlife Bureau), Quezon City, Philippines. 75 p.

Duarte, C.M. 1991. Allometric scaling of seagrass form and productivity. Marine Ecololgy Progress Series, 77 , 289-300.

English, S, Wilkinson, C. and V. Baker. 1994. Survey manual for tropical marine resources. Australia Institute of Marine Science. Townsville, Australia.

Fortes, M.D. and K.F. Santos. 2004. Seagrass ecosystem of the Philippines: Status, problems and management directions. p. 90-95. In DA-BFAR (Department of Agriculture-Bureau of Fisheries and Aquatic Resources). In Turbulent seas: The status of Philippine marine fisheries. Coastal Resource Management Project, Cebu 
City, Philippines. 378 p.

Fortes, M.D. 1995. Seagrasses of East Asia: Environmental and Management Perspectives. RCU/EAS Technical Report Series No. 6. United Nations Environment Programme, Bangkok.

Fortes, M.D. 1990. Seagrasses: a resource unknown in the ASEAN region. ICLARM Education Series No.5, 46p. International Center for Living Aquatic Resources Management, Manila, Philippines.

Frost, M.T., Rowden, A.A. and M.J. Attrill. 1999. Effect of habitat fragmentation on the macroinvertebrate infaunal communities associated with the seagrass Zostera marina L.. Aquatic Conserv: Mar Freshw Ecosyst 9: $255-263$.

Hirst, J.A. and M.J. Attrill. 2008. Small is beautiful: An inverted view of habitat fragmentation in seagrass beds. Estuarine, Coastal and Shelf Science, 78, 811-818.

Nievales, M.F.J. submitted. Status of seagrass meadows and associated sea cucumbers in southern Guimaras after the M/V SOLAR 1 oil spill disaster. UPV Journal of Natural Science.

Paula, J., Fidalgo, P.C, Martins, A. and D. Gove. 2001. Patterns of abundance of seagrasses and associated infaunal communities at Inhaca Island, Mozambique. Estuarine, Coastal and Shelf Science, 53, 307-318.

PCSDS. 2006. In-Depth Coastal/Marine Resources Survey Report for Busuanga Municipality Palawan Council for Sustainable Development, Puerto Princesa City, Philippines.

Tanner, J.E. 2005. Edge effects on fauna in fragmented seagrass meadows. Austral Ecology, 30, 210-218.

Terrados, J., Duarte, C.M., Fortes, M.D., Agawin, N.S.R., Bach, S., Thampanya, U., Kamp-Nielsen, L., Kenworthy, W.J., Geertz-Hansen, O., and J. Vermaat. 1998. Changes in community structure and biomass of seagrass communities along gradients of siltation in SE Asia. Estuarine, Coastal and Shelf Science, 46, 757768.

Tomasko, D.A., Dawes, C.J., Fortes, M.D., Largo, D.B., and M.N.R. Alava. 1993. Conservation on a multi-species seagrass meadows offshore of Negros Oriental, Republic of the Philippines. Botanica Marina, 36(4), 303311.

UNESCO. 2002. An ecological assessment of Ulugan Bay, Palawan, Philippines. CSI info NÅã 12, UNESCO, Paris, 46 pp.

van Houte-Howes, K.S.S., Turner, S.J. and C.A. Pilditch. 2004. Spatial differences in macroinvertebrate communities in intertidal seagrass habitats and unvegetated sediment in three New Zealand estuaries. Estuaries 27: 945-957.

Vermaat, J.E., Agawin, N.S.R., Duarte, C.M., Fortes, M.D., Marba, N. and J.S. Uri. 1995. Meadow maintenance, growth and productivity of a mixed Philippine seagrass bed. Marine Ecology Progress Series, 124, 215-225. 